\title{
Cordonnier Grade 3 Viral Complication, Viral Encephalitis
}

National Cancer Institute

\section{Source}

National Cancer Institute. Cordonnier Grade 3 Viral Complication, Viral Encephalitis. NCI

Thesaurus. Code C138307.

Any viral encephalitis. 